\title{
Effect of zinc deficiency on the weight, cellularity and zinc concentration of different skeletal muscles in the post-weanling rat*
}

\author{
BY MARY J. O'LEARY, C. J. MCCLAIN AND P. V. J. HEGARTY \\ Department of Food Science and Nutrition, University of Minnesota, \\ St Paul, Minnesota 55108 and Veterans Administration Medical Center, \\ Minneapolis, Minnesota 55417, USA
}

(Received 20 March 1979-Accepted 2 May 1979)

1. Zinc-deficient (ZD), weight-restricted (WR), pair-fed (PF) and ad lib.-fed (AL) Sprague-Dawley male rats were killed after feeding the respective $\mathrm{Zn}$-deficient and $\mathrm{Zn}$-supplemented diets from 3 to 8 weeks of age. Animals killed at the start of the experiment served as a baseline control (BC).

2. Four different skeletal muscles - biceps brachii, soleus, plantaris and extensor digitorum longus (EDL) - were studied for changes in weight, the number and diameter of muscle fibres and $\mathrm{Zn}$ concentration.

3. The soleus muscle had the highest concentration of $\mathrm{Zn}$. It was the only muscle to reduce its $\mathrm{Zn}$ concentration due to $\mathrm{Zn}$ deficiency.

4. There was a loss of muscle fibres during normal growth (groups BC v. AL) in the soleus muscle $(P<0.05)$. The estimated length of muscle and the diameter of the muscle fibres in all four muscles increased significantly $(P<0.001)$. Therefore postweanling growth appears to occur as a result of longitudinal and transverse increases in the dimensions of these muscles.

5. The reduction in muscle fibre number in $\mathrm{ZD}$ rats compared to $\mathrm{BC}$ animals may occur within the range of expected fibre loss during normal growth. Fibre loss in ZD rats may be more affected by feeding-patterndependent metabolic changes than by a deficiency of $\mathrm{Zn}$ per se (groups $\mathrm{ZD} v$. WR). Soleus fibre loss in ZD rats may be related to the high $\mathrm{Zn}$ concentration in this muscle.

6. The effect of $\mathrm{Zn}$ deficiency per se on muscle fibre diameter may be inaccurately interpreted by comparing the $\mathrm{ZD}$ animals with their PF and AL controls. There was no significant difference in fibre diameter in any of the four muscles when ZD and WF rats were compared.

Zinc is an essential micronutrient necessary for normal growth in animals and humans (Underwood, 1977). Zn deficiency causes growth retardation which can be reversed with $\mathrm{Zn}$ supplementation. The incidence of human $\mathrm{Zn}$ deficiency in the Middle East (reviewed by Prasad, I976) and in the United States (reviewed by Hambidge \& Walravens, 1976) has stimulated research concerning the effects of $\mathrm{Zn}$ undernutrition upon cellular growth. $\mathrm{Zn}$ deficiency induced inhibition of cellular growth is probably multifactorial in origin. $\mathrm{Zn}$ is required for the synthesis of both nucleic acids and protein (Sandstead, 1973) and $\mathrm{Zn}$ deficiency causes an increase in protein catabolism (reviewed by Hsu \& Anthony, 1975). The growth retardation of $\mathrm{Zn}$ deficiency also relates to reduced food consumption (Miller et al. I968), and impaired food utilization (Kang et al. 1977), and may be affected by feeding-pattern-dependent metabolic changes (Florence \& Quarterman, 1972).

As the largest single tissue in mammals, skeletal muscle is probably responsible for a major component of the growth inhibition associated with $\mathrm{Zn}$ deficiency. Although the activities of $\mathrm{Zn}$ metalloenzymes in muscles from $\mathrm{Zn}$-deficient rats have been studied (Huber \& Gershoff, 1973; Kirchgessner et al. 1977), the effects of $\mathrm{Zn}$ deficiency on muscle fibre number and size have not been investigated. The purpose of this study was to measure muscle weight, the number and diameter of muscle fibres and the concentration of $\mathrm{Zn}$ in skeletal muscle during $\mathrm{Zn}$ deficiency. Four distinct muscles are measured to determine if the nutritional stress is similar in all muscles.

\footnotetext{
* Scientific Journal Series Paper No. 10724, Minnesota Agricultural Experiment Station, University of Minnesota, St Paul, Minnesota 55108.
} 
Table 1. Composition $(\mathrm{g} / \mathrm{kg})$ of zinc-deficient diet given to post-weanling rats

$\begin{array}{lr}\text { Egg-white solids } & 200 \\ \text { Sucrose } & 310 \\ \text { Maize starch } & 312 \\ \text { Corn oil } & 100 \\ \text { Cellulose powder } & 30 \\ \text { Vitamin premix* } & 5 \\ \text { Salt mix } & 40 \\ \text { Choline chloride } & 3\end{array}$

* Vitamin mixture $(\mathrm{g} / \mathrm{kg}$ diet $)$ : retinyl palmitate $9 \cdot 24$; ergocalciferol $\mathrm{I} \cdot 604$; DL- $\alpha$-tocopheryl acetate 40.04; menaphthone I.I98; cyanocobalanin I.815; thiamin mononitrate 4.00 ; riboflavin 8.00 ; nicotinamide 20.00 ; D-calcium pantothenate 12.00 ; pyridoxine hydrochloride 2.00 ; steroylmonoglutamic acid 0.10 ; D-biotin 20.00; myo-inositol dihydrate 80.00; maize starch 800.003 .

$\dagger$ Bernhart \& Tomarelli (I 966) salt mixture (g/kg diet); calcium (as carbonate and phosphate) 75.60; copper (as cupric citrate) 0.046 ; iron (as ferric citrate) 0.558 ; magnesium (as oxide) 2.50; manganese (as citrate) 0.835 ; potassium (as iodide, dibasic phosphate and sulphate) 14.9007; sodium (as chloride and phosphate) 5.20; citric acid 0.227 ; maize starch (in place of zinc citrate) 0.133 .

\section{MATERIALS AND METHODS}

Animals and diets. Male weanling Sprague-Dawley rats (Bio-Lab, St Paul, Minnesota $55 \mathrm{I} 10$ ), weighing from 40 to $55 \mathrm{~g}$ were randomly divided into five groups each containing ten animals. All animals were fed daily a commercially prepared $\mathrm{Zn}$-deficient pelleted diet (Ziegler Brothers Inc., Gardners, Pa. 17324). This diet contains $0.7 \mathrm{mg} \mathrm{Zn} / \mathrm{kg}$ and has no phytate; the nutrient composition is presented in Table $I$.

The diet was fed to the weanling rats for a 5-week period with the following betweengroup variations. $\mathrm{Zn}$-deficient (ZD) and ad lib. control (AL) rats received the diet ad lib. Weight-restricted (WR) animals were weight-paired with $Z D$ animals by restricting the diet so as to maintain a comparable body-weight to the $Z D$ rats. Pair-fed (PF) animals were given an amount of diet equivalent in weight to that consumed by the $\mathrm{ZD}$ animals. Distilled and deionized water with $30 \mathrm{mg}$ added zinc acetate/l was supplied $a d$. lib to WR, $\mathrm{PF}$ and $\mathrm{AL}$ animals. There was no added $\mathrm{Zn}$ in the water of the $\mathrm{ZD}$ animals. Animals killed at the start of the experiment served as the baseline control (BC) group.

The rats were housed individually in stainless-steel wire-bottom cages which were located in an environmentally controlled room with temperature maintained at $2 \mathrm{I} \pm 2^{\circ}$ and alternate $\mathrm{I} 2 \mathrm{~h}$ light and darkness. Zn-deficient pellets were stored at $6 \pm 2^{\circ}$, and handled using plastic gloves, scoop and weighing dishes. Stainless-steel feeders were used with all groups. Distilled and deionized water was supplied in plastic water bottles with silicone stoppers. All items in contact with food and water were soaked for $2-4 \mathrm{~h}$ in EDTA ( $10 \mathrm{~g} / \mathrm{l}$ ) and rinsed three times with distilled and deionized water before use.

Body-weights were determined immediately before killing. The rats were anaesthetized with methoxyfluorane and exsanguinated by heart puncture. All animals were maintained at $2 \mathrm{I} \pm 2^{\circ}$ for $4-5 \mathrm{~h}$ to allow the muscles to enter rigor mortis in situ before dissection. The dissection of muscles in rigor mortis results in no loss of weight compared to muscles dissected immediately post mortem. Muscles in rigor mortis were used because contraction of muscle fibres in the pre-rigor state results in decreased fibre length and increased fibre diameter (Heffron \& Hegarty, 1974).

Skeletal muscle and bone sampling. The biceps brachii from the forelimb and the soleus, plantaris and extensor digitorum longus (EDL) from the hind-limb were dissected intact from origin to insertion, using the description of Greene (1959). All adhering fat and connective tissue were removed from the muscles before weighing. Muscles were fixed individually in neutralized, buffered formalin $(100 \mathrm{ml} / \mathrm{l})$ for at least $10 \mathrm{~d}$. Transverse sections of 


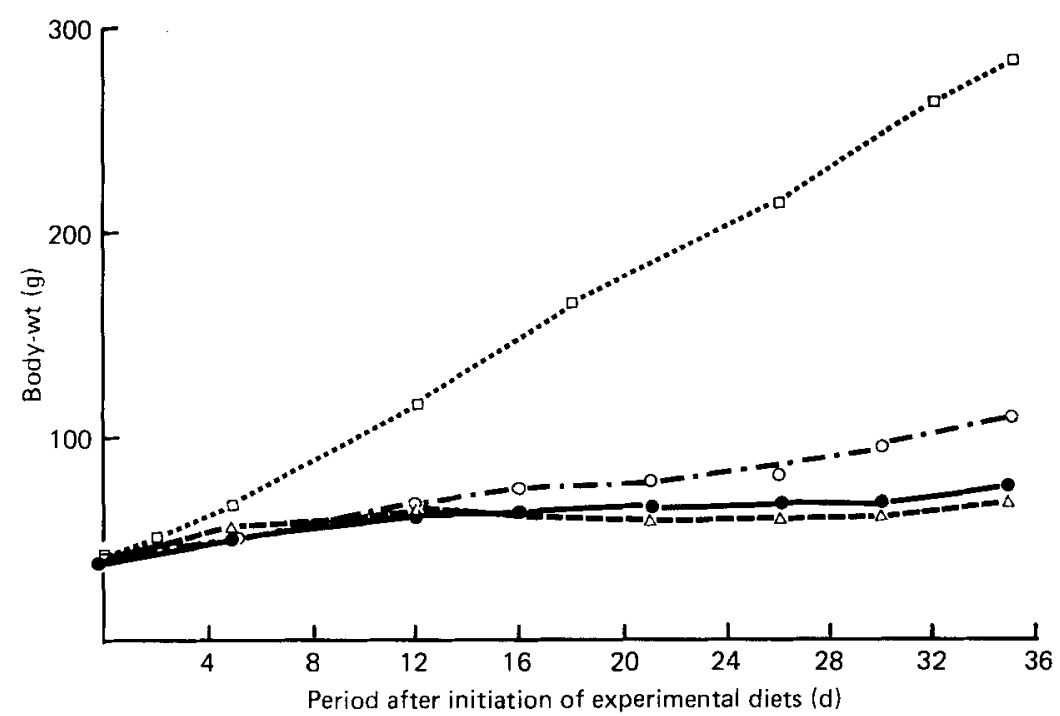

Fig. I. Growth curves for young rats subjected to different dietary zinc treatments. $\square$, Control $\mathrm{Zn}$ diet fed ad lib. ; $\mathrm{O}$, Control $\mathrm{Zn}$ diet pair-fed to the $\mathrm{Zn}$-deficient group; $\bullet$, $\mathrm{Zn}$-deficient diet fed ad lib.; $\triangle$, Control $\mathrm{Zn}$ diet fed at a level that restricted body-weight to that of the Zn-deficient group; for details of diets, see p. 488 and Table 1.

four skeletal muscles from ten animals in all groups were stained by Masson's Trichrome (Lee, 1968), and examined under a light microscope. The lengths of the humerus, tibia and femur were measured as indirect indicators of the length of the muscles attached to the bones.

Muscle fibre number and fibre diameter determination. The Coulter Counter technique as described by Thompson et al. (1979) was used to determine simultaneously total fibre number and fibre diameter from complete transverse sections of the medial portion of each muscle. Fibres were isolated by repeated expulsion from an automated syringe under high pressure onto a nylon-mesh screen. After isolation, the fibres were sized and counted using a model ZB-Coulter Counter (Coulter Electronics, Hialeah, Florida) equipped with an accessory Coulter channelizer to determine the volume of approximately spherical particles. This technique was verified by hand-counting all the fibres in adjacent transverse sections of muscles previously counted using the Coulter Counter. Deviation between the two methods was less than $6 \%$. This is comparable to observations made in our laboratory (Layman et al. 1979).

$\mathrm{Zn}$ concentration determination. Fresh muscle tissue samples to be assayed for $\mathrm{Zn}$ were placed in tubes previously soaked in EDTA $(10 \mathrm{~g} / 1)$ for $3 \mathrm{~h}$. Glassware used for tissue preparation was soaked in nitric acid $(100 \mathrm{ml} / \mathrm{l})$ for $3 \mathrm{~h}$ and rinsed with distilled deionized water. In addition, glassware used in a muffle oven was bleached by heating to $200^{\circ}$ for $8 \mathrm{~h}$ in a mixture of $\mathrm{I}$ vol. concentrated nitric acid and 2 vol. concentrated perchloric acid. The muscles were dried, weighed and dry ashed in a muffle furnace. The ash was dissolved in nitric acid ( $100 \mathrm{ml} / \mathrm{l}$ ) diluted to desired concentrations for $\mathrm{Zn}$ analysis. $\mathrm{Zn}$ determinations were made by atomic absorption spectrophotometry using the Varian Techtron-AA-375 (Varian Associates, 611 Hansen Way, Palo Alto, California 94303).

Statistical methods. The significance of the difference between mean values was determined by the Student's $t$ test. 
Table 2. Body-weights $(g)$ of zinc-deficient and control rats $\dagger$

(Mean values with their standard errors)

$\begin{array}{lcrrcc}\text { Treatment } & \text { Group } & \text { Mean } & \text { SE } & \begin{array}{c}\text { Group } \\ \text { comparisons }\end{array} & \begin{array}{c}\text { Statistical significance } \\ \text { of difference between groups }\end{array} \\ \text { Baseline control } & \text { BC } & 51 \cdot 98 & 1 \cdot 37 & \text { ZD v. WR } & \text { NS } \\ \text { Zn-deficient } & \text { ZD } & 72 \cdot 00 & 3.91 & \text { ZD v. PF } & * * * \\ \text { Weight-resticted } & \text { WR } & 69.56 & 3.17 & \text { ZD v. AL } & * * * \\ \text { Pair-fed } & \text { PF } & 111 \cdot 33 & 2.35 & \text { BC } v \text {. AL } & * * * \\ \text { Ad lib. control } & \text { AL } & 285.00 & 13.1 \text { II } & & \end{array}$

NS, not significant.

Significance of difference between mean values: ${ }^{* * *} P<0.001$.

$\dagger$ For details, see p. 489.

Table 3. Muscle weights (mg) of four skeletal muscles from zinc-deficient and control rats $\dagger$

(Mean values with their standard errors)

\begin{tabular}{|c|c|c|c|c|c|c|c|c|c|}
\hline \multirow{2}{*}{$\begin{array}{l}\text { Muscle } \ldots \\
\text { Treatment }\end{array}$} & \multirow[b]{2}{*}{ Group } & \multicolumn{2}{|c|}{ Biceps brachii } & \multicolumn{2}{|c|}{ Soleus } & \multicolumn{2}{|c|}{ Plantaris } & \multicolumn{2}{|c|}{ EDL } \\
\hline & & Mean & SE & Mean & SE & Mean & SE & Mean & SE \\
\hline Baseline control & BC & $39 \cdot 1$ & $2 \cdot I$ & $19 \cdot 3$ & $1 \cdot 3$ & $33 \cdot 3$ & 1.6 & 23.9 & $I \cdot I$ \\
\hline Zn-deficient & $\mathrm{ZD}$ & $65 \cdot 4$ & $3 \cdot 0$ & 25.4 & $1 \cdot 4$ & $63 \cdot 4$ & $5 \cdot 7$ & $36 \cdot 9$ & $3 \cdot 6$ \\
\hline Weight-restricted & WR & $69 \cdot 6$ & 3.8 & 29.8 & 1.5 & $6 \mathrm{t} \cdot 8$ & $3 \cdot 9$ & $39 \cdot 8$ & $2 \cdot 2$ \\
\hline Pair-fed & PF & $105 \cdot 8$ & 3.8 & $45 \cdot 4$ & 1.9 & $110 \cdot 0$ & $4 \cdot 4$ & $67 \cdot 3$ & I.7 \\
\hline Ad lib. control & $\mathrm{AL}$ & 197.2 & $9 \cdot 6$ & 94.0 & $5 \cdot 5$ & 288.9 & $8 \cdot 9$ & 145.7 & $6 \cdot 2$ \\
\hline
\end{tabular}

Group comparison

ZD v. WR

ZD v. PF

$\mathrm{ZD}$ v. AL

$\mathrm{BC} v . \mathrm{AL}$

Statistical significance of difference between groups

NS, not significant; EDL, extensor digitorum longus.

Significance of the difference between mean values: ${ }^{*} P<0.05,{ }^{* * *} P<0.001$.

$\dagger$ For details, see p. 489 .

\section{RESULTS AND DISCUSSION}

$\mathrm{Zn}$ deficiency caused a reduced weight gain (Fig. I and Table 2). The mean body-weight of the ZD rats was $35 \%$ less than that of the PF animals $(P<0.001)$. This difference is probably a manifestation of the previously described impairment of nucleic acid and protein synthesis, increased protein catabolism, and may be affected by impaired food utilization. The lower $(P<0.001)$ mean body-weight of the PF animals compared to the AL animals can be attributed to the reduced food consumption characteristic of $\mathrm{Zn}$ deficiency. Indeed, Chesters \& Quarterman (1970) reported that voluntary food intake of $\mathrm{Zn}$-deficient rats fell to $70 \%$ that of control rats.

Similarities exist between changes in body-weight and changes in muscle weights when certain groups are compared (Tables 2 and 3). For example, the PF rats increased in bodyweight by a factor of $\mathrm{I} \cdot 55$ compared to the $\mathrm{ZD}$ animals. The corresponding increase in the biceps brachii, soleus, plantaris and EDL was $I \cdot 62, I \cdot 79, I \cdot 74$ and $I \cdot 82$ respectively. These values suggest that, in this study, the rate of increase in body-weight may be a good indication of muscle growth. 
Table 4. Zinc concentration ( $\mu \mathrm{g} / \mathrm{g}$ dry weight) of four skeletal muscles from zinc-deficient and control rats

(Mean values with their standard errors)

\begin{tabular}{llrc} 
Muscle ... & & \multicolumn{2}{c}{ Biceps brachii } \\
\multicolumn{1}{c}{ Treatment } & & Mean & SE \\
Baseline control & BC & 1.36 & 0.15 \\
Zn-deficient & ZD & 1.20 & 0.08 \\
Weight-restricted & WR & 1.32 & 0.12 \\
Pair-fed & PF & 1.14 & 0.05 \\
Ad lib. control & AL & 0.92 & 0.02 \\
& &
\end{tabular}

\begin{tabular}{cc} 
Mean & SE \\
3.76 & 0.34 \\
3.39 & 0.08 \\
4.20 & 0.14 \\
3.60 & 0.13 \\
3.61 & 0.16 \\
\hline
\end{tabular}

\begin{tabular}{|c|c|}
\hline \multicolumn{2}{|c|}{ Plantaris } \\
\hline Mean & $\mathrm{SE}$ \\
\hline I $\cdot 54$ & 0.13 \\
\hline $1 \cdot 20$ & 0.18 \\
\hline $1 \cdot 16$ & 0.09 \\
\hline I.0I & 0.05 \\
\hline $1 \cdot 58$ & 0.24 \\
\hline
\end{tabular}

\begin{tabular}{ll} 
Mean & SE \\
1.31 & 0.11 \\
1.57 & 0.30 \\
1.61 & 0.22 \\
1.05 & 0.09 \\
1.09 & 0.07 \\
\hline
\end{tabular}

Group comparison

ZD v. WR

ZD v. PF

$\mathrm{ZD}$ v. AL

BC v. AL

\begin{tabular}{llll}
\multicolumn{4}{c}{ Statistical significance of difference between groups } \\
\hline NS & $* * *$ & NS & NS \\
NS & NS & NS & NS \\
NS & NS & NS & NS \\
NS & NS & NS & NS
\end{tabular}

NS, not significant.

Significance of difference between mean values: ${ }^{* * *} P<0.001$.

During the 5-week period of normal growth (BC group compared to AL group), mean weights of the four muscles increased significantly $(P<0.001)$ (Table 3$)$. Mean weights of muscles from the ZD rats were significantly less than their PF and AL controls $(P<0.001)$. With the exception of the soleus $(P<0.05)$, the weights of the biceps brachii, plantaris and EDL muscles from the ZD rats were not significantly different from the WR group. This difference in the weight of the soleus may be related to the high $\mathrm{Zn}$ content of the soleus muscle. The red soleus muscle is composed primarily of slow twitch, oxidative fibres (Ariano et al. 1973). Red muscle has been reported to contain a 300-700\% higher $\mathrm{Zn}$ concentration than the primarily fast twitch, glycolytic (white) muscles (Cassens et al. 1967). The plantaris, EDL and biceps brachii belong to this latter category containing less $\mathrm{Zn}$. Indeed, when $\mathrm{Zn}$ content of the four different muscles was evaluated, the soleus had significantly higher $\mathrm{Zn}$ content than all other muscles and in only the soleus was there a significant difference in muscle $\mathrm{Zn}$ when the $\mathrm{ZD}$ group was compared to the WR group $(P<0.00 \mathrm{I})$ (Table 4$)$.

Confusion exists regarding postnatal changes in the cellularity of skeletal muscles during normal growth and dietary restriction. Although much of the literature concludes that muscle fibre number remains constant during normal growth (Rowe \& Goldspink, I969; Burleigh, 1974), several investigators report a post-weanling loss of muscle fibres (Bendall \& Voyle, 1967; Inokuchi et al. 1975; Rayne \& Crawford, 1975; Layman et al. 1979). Muscle fibre number remains constant in food-restricted mice (Rowe, 1968) and pigs (Strickland et al. 1975), but is reported to decrease in human infants dying of protein-energy malnutrition (Montgomery, 1962) and in rats after prolonged starvation (Kim \& Hegarty, I 978; Layman, 1978). The results of this investigation support reports showing some fibre loss during normal growth. Cell number determinations indicated fibre losses of 3 and $11 \%$ in the biceps brachii and plantaris muscles, respectively, and a significant $28 \%$ fibre loss $(P<0.05)$ in the soleus muscle (BC group compared to AL group) (Table 5). These values agree with those of Layman et al. (1979) who reported a 12, 20, 26 and $2 \%$ decrease in muscle fibre number in biceps brachii, soleus, plantaris and EDL muscles respectively during normal growth between 25 and $53 \mathrm{~d}$ of age. 
Table 5. Mean fibre number of four skeletal muscles from zinc-deficient and control rats

(Mean values with their standard errors)

\begin{tabular}{|c|c|c|c|c|c|c|c|c|c|}
\hline \multirow{2}{*}{$\begin{array}{c}\text { Muscle } \ldots \\
\text { Treatment }\end{array}$} & \multirow[b]{2}{*}{ Group } & \multicolumn{2}{|c|}{ Biceps brachii } & \multicolumn{2}{|c|}{ Soleus } & \multicolumn{2}{|c|}{ Plantaris } & \multicolumn{2}{|c|}{ EDL } \\
\hline & & Mean & SE & Mean & SE & Mean & SE & Mean & SE \\
\hline Baseline control & $\mathrm{BC}$ & 8746 & 539 & 3024 & 256 & 5065 & 263 & 3862 & 285 \\
\hline $\mathrm{Zn}$-deficient & $\mathrm{ZD}$ & 8470 & 343 & 2481 & 263 & 4208 & 463 & 3427 & 232 \\
\hline Weight-restricted & WR & 8920 & 423 & 3245 & 234 & 4712 & 242 & 4428 & 202 \\
\hline Pair-fed & PF & 8062 & 407 & 2566 & 175 & 4545 & 327 & 4302 & 317 \\
\hline Ad lib. control & $\mathrm{AL}$ & 8438 & 378 & 2187 & 130 & 4502 & 107 & 4331 & 295 \\
\hline
\end{tabular}

Group comparison

Statistical significance of difference between groups

ZD v. WR

ZD v. PF

ZD $v . A I$

$\mathrm{BC}$ v. ZD

$\mathrm{BC}$ y. AL

$\begin{array}{lccc} & * & \text { NS } & * \\ \text { NS } & \text { NS } & \text { NS } & * \\ \text { NS } & \text { NS } & \text { NS } & \text { NS } \\ \text { NS } & \text { NS } & \text { NS } & \text { NS } \\ \text { NS } & * & \text { NS } & \text { NS }\end{array}$

NS, not significant.

Significance of the difference between mean values: ${ }^{*} P<0.05$.

Changes in mean fibre number during $\mathrm{Zn}$ deficiency suggest a loss of fibres (BC group $v$. $\mathrm{ZD}$ group). This apparent loss may, however, be an artifact due to failure to distinguish between fibres lost during $\mathrm{Zn}$ deficiency and fibres lost during the normal process of growth. The $3,18,17$ and $\mathrm{I} \%$ loss in the biceps brachii, soleus, plantaris and EDL muscles respectively, observed in group ZD compared to group BC, may occur within the previously described range of expected fibre loss during normal growth. Indeed, there is no significant difference in fibre number for any of the muscles when groups $\mathrm{ZD}$ and $\mathrm{AL}$ are compared. This can be interpreted to signify that the number of fibres in these skeletal muscles is unaffected by a deficiency of $\mathrm{Zn}$, and that the reduction in muscle fibre number in $\mathrm{ZD}$ animals is consistent with the loss expected during normal growth.

There is an apparent difference in fibre number in WR animals compared to ZD animals. The WR rats have 5, 24, I I and $23 \%$ more muscle fibres in the biceps brachii, soleus, plantaris and EDL muscles respectively. Muscle fibre number is also greater for all muscles in the WR rats compared to the AL rats. This may be a result of feeding-pattern-dependent metabolic changes (Florence \& Quarterman, 1972). The WR rats were observed to eat their Zn-supplemented diet very rapidly, and may have developed physiological changes characteristic of meal-eaters in contrast to the nibbling $\mathrm{ZD}$ and AL rats.

In the instance of the soleus, the significantly lower fibre number $(P<0.05)$ in $\mathrm{ZD}$ rats compared to WR animals may be related to the high $\mathrm{Zn}$ content of this muscle. It is only in the soleus muscle that comparison of ZD and WR rats shows significant changes in muscle fibre number, weight and $\mathrm{Zn}$ concentration.

The variation in fibre number values is similar to that reported recently by Bedi et al. (1978). The latter workers manually counted the number of fibres in the EDL muscle of the rat and found an $18 \%$ reduction in fibre number due to partial undernutrition, but this large difference was not statistically significant. It seems, therefore, that regardless of which technique is used to determine the number of fibres in the particular muscle, large differences can be expected in the values obtained within a group of animals due to individual animal variation.

Muscle fibre diameter increased significantly $(P<0.00 \mathrm{I})$ in the four muscles during the 
Table 6. Mean fibre diameter $(\mu m)$ of four skeletal muscles from zinc-deficient and control rats

(Mean values with their standard errors)

\begin{tabular}{|c|c|c|c|c|c|c|c|c|c|}
\hline \multirow{2}{*}{$\begin{array}{c}\text { Muscle } \ldots \\
\text { Treatment }\end{array}$} & \multirow[b]{2}{*}{ Group } & \multicolumn{2}{|c|}{ Biceps brachii } & \multicolumn{2}{|c|}{ Soleus } & \multicolumn{2}{|c|}{ Plantaris } & \multicolumn{2}{|c|}{ EDL } \\
\hline & & Mean & SE & Mean & SE & Mean & SE & Mean & $\mathrm{SE}$ \\
\hline Baseline control & $\mathrm{BC}$. & 20.83 & 0.55 & $23 \cdot 21$ & 0.55 & $20 \cdot 24$ & 0.62 & $19 \cdot 36$ & 0.20 \\
\hline Zn-deficient & $Z D$ & 29.02 & $1 \cdot 56$ & $27 \cdot 68$ & 1.52 & $25 \cdot 75$ & $\mathrm{I} \cdot 54$ & $26 \cdot 39$ & $2 \cdot 06$ \\
\hline Weight-restricted & WR & 27.95 & 0.96 & $28 \cdot 69$ & 1.62 & $27 \cdot 53$ & $1 \cdot 46$ & $24 \cdot 10$ & 0.98 \\
\hline Pair-fed & $\mathrm{PF}$ & $32 \cdot 67$ & 0.97 & $37 \cdot 96$ & 0.80 & 35.62 & $I \cdot 35$ & $30 \cdot 23$ & 0.78 \\
\hline Ad lib. control & $\mathrm{AL}$ & $41 \cdot 84$ & $1 \cdot 42$ & $48 \cdot 19$ & $1 \cdot 18$ & $50 \cdot 75$ & 0.90 & $39 \cdot 50$ & $I \cdot I 6$ \\
\hline
\end{tabular}

Group comparison

ZD v. WR

ZD v. PF

ZD v. AL

Statistical significance of difference between groups

$\begin{array}{llll}\text { NS } & \text { NS } & \text { NS } & \text { NS } \\ \text { NS } & * * * & * * * & \text { NS } \\ * * * & * * * & * * * & * * *\end{array}$

NS, not significant.

Significance of the difference between mean values: $* * * P<0.001$.

Table 7. Bone lengths $(\mathrm{cm})$ of femur, tibia and humerus from zinc-deficient and control rats

(Mean values with their standard errors)

\begin{tabular}{|c|c|c|c|c|c|c|c|}
\hline \multirow{2}{*}{$\begin{array}{l}\text { Bone ... } \\
\text { Treatment }\end{array}$} & \multirow[b]{2}{*}{ Group } & \multicolumn{2}{|c|}{ Femur } & \multicolumn{2}{|c|}{ Tibia } & \multicolumn{2}{|c|}{ Humerus } \\
\hline & & Mean & $\mathrm{SE}$ & Mean & SE & Mean & SE \\
\hline Baseline control & $\mathrm{BC}$ & $\mathrm{I} \cdot 82$ & 0.02 & $2 \cdot 23$ & 0.02 & 1.59 & 0.03 \\
\hline Zn-deficient & $Z D$ & $2 \cdot 39$ & 0.05 & $2 \cdot 85$ & 0.05 & $1 \cdot 94$ & 0.04 \\
\hline Weight-restricted & WR & $2 \cdot 46$ & 0.03 & 2.91 & 0.05 & 1.97 & 0.02 \\
\hline Pair-fed & $\mathrm{PF}$ & $2 \cdot 79$ & 0.09 & $3 \cdot 23$ & 0.03 & $2 \cdot 14$ & 0.02 \\
\hline Ad lib. control & $\mathrm{AL}$ & $3 \cdot 34$ & 0.02 & 3.85 & 0.04 & $2 \cdot 59$ & 0.03 \\
\hline
\end{tabular}

Group comparison

ZD v. WR

$\mathrm{ZD}$ v. $\mathrm{PF}$

ZD v. AL

Statistical significance of difference between groups

NS, not significant.

Significance of the difference between mean values: *** $P<0.00 \mathrm{I}$.

5-week period of normal growth (groups BC $v$. AL) (Table 6). Muscle lengths also increased as indicated by the significantly longer $(P<0.001)$ mean lengths of the femur, tibia and humerus bones (Table 7$)$. Since muscle weight increased significantly $(P<0.001)$ during this period (Table 3 ) and muscle fibre number apparently decreased (Table 5) post-weanling growth must occur entirely as a result of longitudinal and transverse increases in the dimensions of muscle fibres.

The effect of Zn deficiency per se on muscle fibre diameter (groups ZD $v$. WR) may be inaccurately interpreted by comparing the $\mathrm{ZD}$ animals with their $\mathrm{PF}$ and $\mathrm{AL}$ controls (Table 6). The comparison of groups $\mathrm{ZD} v$. AL indicates a significant inhibition $(P<0.001)$ of fibre growth in diameter of all muscles during $\mathrm{Zn}$ deficiency. Muscle fibre diameter is also reduced in all muscles of the ZD rats compared to their PF rats, and the difference is significant in the soleus and plantaris muscles $(P<0.00 \mathrm{I})$. This is consistent with the 
observations of Layman et al. (1979) of more rapid muscle development in the soleus and plantaris compared to the biceps brachii and EDL with regard to increase in fibre diameter. Comparisons of groups $\mathrm{ZD} v$. AL and ZD $v$. PF interpret these results to signify that there is inhibition of growth in fibre diameter during $\mathrm{Zn}$ deficiency. However, when the $\mathrm{ZD}$ animals are compared with their WR controls, there is no significant difference in fibre diameter in any of the four muscles, suggesting that $\mathrm{Zn}$ deficiency per se has no significant effect on muscle diameter. Similar intergroup differences are seen in comparisons of muscle weight (except soleus) (Table 3), and muscle length (Table 7). Thus, in the interpretation of changes in these measures of muscle growth, it seems important to separate the effect of a deficiency of $\mathrm{Zn}$ per se (groups ZD $v$. WR), from the total effect of $\mathrm{Zn}$ deficiency (groups $\mathrm{ZD} v$. AL) and the effect of altered food efficiency and intake (groups ZD v. PF) produced by a deficiency of dietary $\mathrm{Zn}$.

This study confirms that $\mathrm{Zn}$ deficiency causes severe growth retardation, and that ZD rats are markedly growth retarded even when compared to their PF controls. The effects of $\mathrm{Zn}$ deficiency seem to be most marked on the red (soleus) muscle which contains a high concentration of $\mathrm{Zn}$. The soleus muscle weighed less, had a lower fibre number, and contained less $\mathrm{Zn}$ when $\mathrm{ZD}$ rats were compared to WR controls and this was the only muscle to demonstrate such an effect.

Given this, muscle fibre number and diameter remain relatively unaffected by a deficiency of $\mathrm{Zn}$ per se (groups $\mathrm{ZD} v$. WR). The change in mean fibre number seen during $\mathrm{Zn}$ deficiency may have occurred within the range of expected fibre loss during normal growth (groups BC v. AL), and may have been more affected by feeding-pattern-dependent metabolic changes than by $\mathrm{Zn}$ deficiency per se. Similarly, when muscles were evaluated by light microscopy, no apparent structural changes were noted in ZD rats compared to all other groups. There were no significant changes in fibre diameter in any of the muscles when $Z D$ and WR rats were compared.

The possible effect of $\mathrm{Zn}$ deficiency on skeletal muscle cellularity during more rapid periods of growth such as pregnancy and lactation has yet to be evaluated.

\section{REFERENCES}

Ariano, M. A., Armstrong, R. B. \& Edgerton, V. R. (1973). J. Histochem. Cytochem 2I, 51.

Bedi, K. S., Mahon, M. \& Smart, J. L. (1978). Proc. Nutr. Soc. 37, 59 A.

Bendall, J. R. \& Voyle, C. A. (1967). J. Fd Technol. 2, 259.

Bernhart F. W. \& Tomarelli, R. M. (1966). J. Nutr. 89, 495.

Burleigh, I. G. (1974). Biol. Rev. 49, 267.

Cassens, R. G., Hoekstra, W. G., Faltin, E. C. \& Briskey, E. J. (1967). Am. J. Physiol. 212, 688.

Chesters, R. K. \& Quarterman, J. (1970). Br. J. Nutr. 24, I06I.

Florence, E. \& Quarterman, J. (1972). Br, J. Nutr. 28, 63.

Greene, E. C. (1959). Anatomy of the Rat, p. 3i. New York: Hafner.

Hambidge, M. K. \& Walravens, P. A. (1976). In Trace Elements in Human Health and Disease. Vol. I. Zinc and Copper, p. 2I [A. S. Prasad and D. Oberleas, editors]. New York: Academic Press.

Heffron, J. J. A. \& Hegarty, P. V. J. (1974). Comp. Biochem. Physiol. 49A, 43.

Hsu, J. M. \& Anthony, W. L. (1975). J. Nutr. ro5, 26.

Huber, A. M. \& Gershoff, S. N. (1973). J. Nutr. 103, 1175.

Inokuchi, S., Ishikawa, H., Iwamoto, S. \& Kimura, T. (1975). Hum. Biol. 47, 231.

Kang, H. K., Harvey, P. N., Valentine, J. L. \& Swendseid, M. E. (I977). Clin. Chem. 23, I 834.

Kim, K. O. \& Hegarty, P. V. J. (1978). Proc. Nutr. Soc. 37, I14A.

Kirchgessner, M., Roth, H. P., Spoeri, R., Schnegg, A., Kellner, R. J. \& Weigand, E. (1977). Nutr. Metab. 2I, 119 .

Layman, D. K. (1978). Biochemical and morphological changes in skeletal muscle fibers during normal growth and prolonged starvation. $\mathrm{PhD}$ Thesis, University of Minnesota.

Layman, D. K., Hegarty, P. V. J. \& Swan, P. B. (I979). J. Anat. (In the Press).

Lee, G. L. (1968). Manual of Histologic Staining Methods, 3rd ed., p. 94. New York: McGraw-Hill.

Miller, E. R., Luecke, R. W., Ullrey, D. E., Baltzer, B. V., Bradley, B. L. \& Hoefer, J. A. (1968). J. Nutr. 95, 278.

Montgomery, R. D. (1962). J. Clin. Path. 15, 511. 
Prasad, A. S. (1976). In Trace Elements in Human Health and Disease. Vol. I. Zinc and Copper, p. I [A. S. Prasad and D. Oberleas, editors]. New York: Academic Press.

Rayne, J. \& Crawford, G. N. C. (1975). J. Anat. 119, 347.

Rowe, R. W. D. (1968). J. exp. Zool. x67, 353.

Rowe, R. W. D. \& Goldspink, G. (1969). J. Anat. ro4, 519.

Sandstead, H. H. (1973). Am. J. clin. Nutr. 26, 1251.

Stickland, N. C., Widdowson, E. M. \& Goldspink, G. (1975). Br. J. Nutr. 34, 42 I.

Thompson, E. H., Levine, A. S., Hegarty, P. V. J. \& Allen, C. E. (1979). J. Anim. Sci. 48, 328.

Underwood, E. J. (1977). In Trace Elements in Human and Animal Nutrition. New York: Academic Press. 